\title{
Isolation and Identification of the Causal Pathogens for Kiwifruit Bacterial Canker and the Isolation of the Antagonistic Endophytic Fungi From Kiwifruit in Sichuan, China
}

\author{
Jinyi Yan $^{1^{*}}$, Yongliang Cui ${ }^{1 *}$, Jian Ding ${ }^{2}$, Liangqiang Zhou ${ }^{2}$, Zuqiang Cheng ${ }^{2} \&$ Min Zhang ${ }^{1}$ \\ ${ }^{1}$ Department of Agriculture, Sichuan Agriculture University, Chengdu, China \\ ${ }^{2}$ Sichuan Provincial Institute of Natural Resource Sciences, Chengdu, China \\ Correspondence: Min Zhang, Department of Agriculture, Sichuan Agriculture University, Chengdu, China. \\ E-mail: yalanmin@126.com \\ ${ }^{*}$ These two authors contribute equal work to this paper.
}

Received: April 16, 2013 Accepted: May 18, 2013 Online Published: June 15, 2013

doi:10.5539/jas.v5n7p262 URL: http://dx.doi.org/10.5539/jas.v5n7p262

\begin{abstract}
The kiwifruit bacterial canker has been recognized as the main kiwifruit pathogen in Sichuan and acquired strong resistance to chemicals during its long evolution under chemical evolutionary pressure. Base on biochemical testing, pathogenic testing and phylogenetic analyses, the results shown that Pseudomonas syringae $p v$. actinidiae is the causal agents of the "Hongyang" kiwifruit bacterial canker disease. Besides this bacterial pathogen, 14 endophytic fungi of kiwifruit leaves were also isolated and identified, including Penicillium sp. Colletotrichum sp. Phomopsis sp. Alternaria sp. and Nigrospora sp. 8 endophytic fungi were obtained from branches, such as Alternaria sp. Nigrospora sp. Phomopsis sp.and Sordaria sp. and one of the endophytic fungi Nigrospora sp. (No.J2) from branch showed good antagonistic activities to Pseudomonas syringae pv. actinidiae in vitro with the inhibition zone of $14 \mathrm{~mm}$, therefore it has the potential of being used as a biological control agent against kiwifruit bacterial canker.
\end{abstract}

Keywords: kiwifruit bacterial canker, endophytic fungi, "HongYang", China, bio-control

\section{Introduction}

China is one of the most important production areas for kiwifruit around the world and known as the country of origin of kiwifruit. Sichuan province, located in southwest of China, has a wealth of natural resources with about $700,000,000 \mathrm{~m}^{2}$ of kiwifruit growing areas and an annual production of 84,000,000 $\mathrm{kg}$ where "HongYang" kiwifruit is especially characterized with red color, good taste, and rich nutrient, renowned as the "national variety protection resource" and has become the main kiwifruit specie in Sichuan with good economical benefits and cultural values. However, the kiwifruit bacteria canker constitute causing serious yield loss in this area. The main disease symptoms were brown spots surrounded by yellow haloes on leaves and reddish exudates on twigs and trunks (Figure 1) which were similar to those caused by the bacterium Pseudomonas syringae pv. actinidiae (Psa.) in previous reports (Serizawa et al., 1989). Several studies have reported the kiwifruit bacterial canker in other countries, but the comprehensive research on the pathogens of kiwifruit bacterial canker in "HongYang" is still seldom.

Endophytes are organisms able to live in plant tissues for a consistent part of their life cycle without inducing substantial damages to the host (Downing et al., 2000; Ryu et al., 2005). It is also known that endophytic fungi statement in abstract and introduction are an important source of bioactive compounds, some showing a real antifungal activity (Shimizu et al., 2000). As matter of facts, many have been already used as fungicide in a commercial way ( $\mathrm{Li}$ et al., 2005). The outburst condition of kiwifruit bacterial canker in "HongYang" is especially serious in 2012, however, there is a particular kiwifruit plant still in healthy state while all of the kiwifruit plants surrounded were seriously affected. Therefore we have reason to suspect that maybe is the endophytic fungi in that particular plant that works. There are many researches on endophytic fungi in different plants, but no reports concern kiwifruit.

In this study, we isolated and identified the kiwifruit bacterial canker pathogen on "HongYang" from reddish 
exudates. Furthermore, endophytic fungi from kiwifruit leaves and branches were obtained; these fungal endophytes were identified and the antimicrobial activity against the pathogen of kiwifruit bacterial canker has been tested. Thus the objective of the study was to find the effective antagonistic strains from health kiwifruit plant preliminary, in order to find potential biological control agents against kiwifruit bacterial canker.

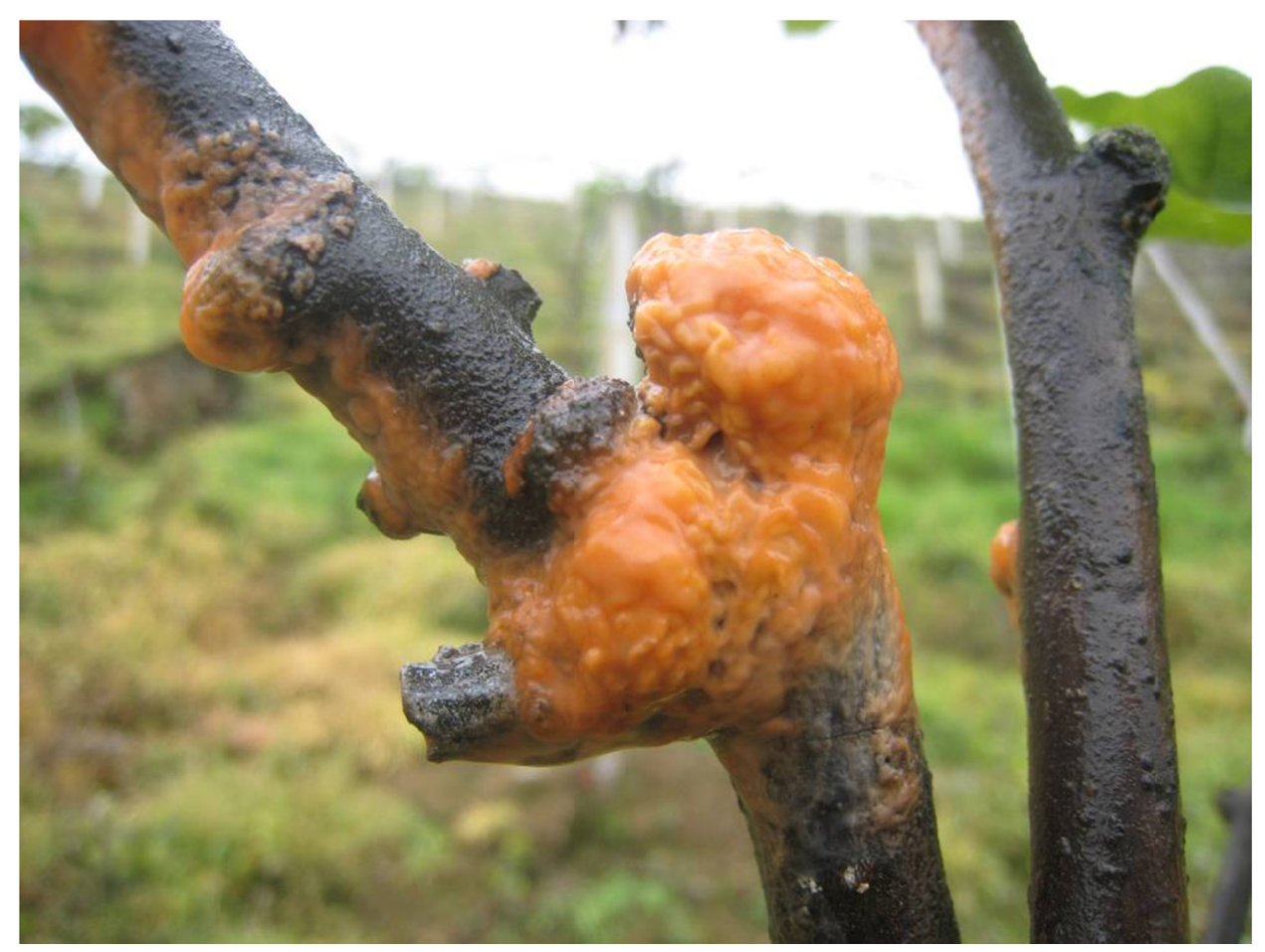

Figure 1. The symptom of the kiwifruit bacterial canker in "HongYang", China: the main disease symptoms were brown spots surrounded by yellow haloes on leaves, and reddish exudates on twigs and trunks

\section{Materials and Methods}

\subsection{Isolation and Identification of the Pathogen}

Since the pathogens of kiwifruit bacterial canker in different places may have slight differences, three main "HongYang" producing areas in Sichuan with different altitudes and soil conditions: Ya/an $\left(29^{\circ} 58^{\prime} 59.45^{\prime \prime} \mathrm{N}\right.$, $\left.103^{\circ} 0^{\prime} 40.72^{\prime \prime} \mathrm{E}\right)$, Dujiangyan $\left(31^{\circ} 0^{\prime} 2.99^{\prime \prime} \mathrm{N}, 103^{\circ} 37^{\prime} 2.47^{\prime \prime} \mathrm{E}\right)$, Shifang $\left(31^{\circ} 7^{\prime} 44.38^{\prime \prime} \mathrm{N}, 104^{\circ} 9^{\prime} 54.02^{\prime \prime} \mathrm{E}\right)$ were chosen in which the bacterial canker attack was severe.

Bacterium colonies were isolated from the reddish exudates produced on the trunks of infected kiwifruit vines in April, 2012. To isolate the pathogen, the reddish exudates were collected and shaken into a homogeneous mixture. The mixture were directly tested for detectable amplicons by polymerase chain reaction (PCR) using the primers F1 (TTTTGCTTTGCACACCCGATTT) / R2 (CACGCACCCTTCAATCAGGATG) and F3 (ACCTGGTGAAGTTGGTCAGAGC) / R4 (CGCACCCTTCAATCAGGATA) as it advised in the paper (Rees-George et al., 2010). PCR was performed using an Eppendorf Master Cycler Gradient (ENDORF Mastercycler gradient 5331, German).

The amplified products were then analyzed on a $2 \%$ agarose gel and stained with ethidium bromide $(0.5 \mu \mathrm{g} / \mathrm{ml})$. The gels were visualized under UV light in a transilluminator. The none-band-mixture was removed. From the mixtures which yielded amplicons a tenfold serial dilution was performed and aliquots $(0.1 \mathrm{ml})$ of the dilutions were spread onto the plates of nutrient agar (NA medium) (beef extract $3 \mathrm{~g}$, peptone $10 \mathrm{~g}, \mathrm{NaCl} 5 \mathrm{~g}$, agar $20 \mathrm{~g}$, distilled water $1000 \mathrm{ml}$ ). Plates were incubated at $28^{\circ} \mathrm{C}$ for up to $72 \mathrm{~h}$. From the plates, Psa.-like colonies were chosen and streaked on NA plates for $72 \mathrm{~h}$ to confirm their purity and inoculated into the liquid medium for $48 \mathrm{~h}$ under $28^{\circ} \mathrm{C}$. Total DNA was extracted from bacterium liquid medium by Genorise Universal DNA Mini Kit (Genorise Universal DNA Mini Kit 101076, America) following the manufacturer"s instructions. The strains were detected by primers F1 (TTTTGCTTTGCACACCCGATTT) / R2 (CACGCACCCTTCAATCAGGATG) 
and F3 (ACCTGGTGAAGTTGGTCAGAGC) / R4 (CGCACCCTTCAATCAGGATA). The sequences were then compared to the database available at the National Center for Biotechnology Information (NCBI) using their Blast Search Software on the NCBI website (http://www.ncbi.nlm.nih.gov/genbank).

The biochemical test was performed according to Lelliott \& Stead (Lelliott \& Stead, 1998), levan production, presence of oxidase, Gram staining, arginine dihydrolase, metabolism of glucose, presence of fluorescent pigment on King"s medium B, tobacco-hypersensitivity reaction. The effect of temperature on growth was measured according to the amount of the bacteria produced after being incubated for $24 \mathrm{~h}$ at different temperatures (Shanghai Yiheng light incubator MGC-250BP-2, Shanghai). The relationship between the growth and the time was monitored according to the amount of bacteria incubated at $28^{\circ} \mathrm{C}$ for different amount of times. Shape of the pathogen was observed by a scanning electronic microscope (Hitachi cold field emission scanning electronic microscope S-4800, Japan).

Three 2-year-old healthy plants were inoculated with about $1 \times 10^{7} \mathrm{CFU} \mathrm{ml}^{-1}$ of bacterium suspensions as described by Takikawa (Takikawa et al., 1989) as compared to water control. Only isolates bacterium reddish exudates from canes produced symptoms similar to those naturally observed on the buds and branches and identify the bacterium by molecular tests. The control plants were similarly incubated with sterile water.

\subsection{Isolation and Identification of the Endophytic Fungi}

In July 2012, branch and leaf samples of the particular healthy kiwifruit plant were taken and transported in plastic bags in a cooler from the field sites to the laboratory. The isolation was carried out as following: branches and leaves were washed under running tap water for $3 \mathrm{~min}$ and than air-dried. Samples were pieced into the size of about $0.5 \mathrm{~cm}$ using sterile surgical blades, soaked in $75 \%$ ethanol for $2 \mathrm{~min}$, washed by sterile distilled water for $3 \mathrm{~min}$, immersed in $0.1 \% \mathrm{HgCl}_{2}$ for $20 \mathrm{~s}$, and then washed by sterile distilled water for $1 \mathrm{~min}$. The treated pieces were cultured on the potato dextrose agar (PDA) medium (potato $200 \mathrm{~g}$, glucose $17 \mathrm{~g}$, agar $17 \mathrm{~g}$, water $1000 \mathrm{ml})$ supplemented with streptomycin $(100 \mu \mathrm{g} / \mathrm{ml})$ sequentially.

Total DNA was extracted by CTAB method (Wu et al., 2009) and PCR was performed using an Eppendorf Master Cycler Gradient. The strains were detected by the primers ITS1 (TCCGTAGGTGAACCTGCGG) and ITS4 (TCCTCCGCTTATTGATATGC). The amplified DNA fragments were purified and the sequences were then compared to the database available at the NCBI using their Blast Search Software on the NCBI website (http://www.ncbi.nlm.nih.gov/genbank).

\subsection{The Antibacterial Activity Test of the Endophytic Fungi}

The antibacterial activity was determined using the oxford-cup-plate method (cited literatures). $1 \times 10^{7} \mathrm{CFU}$ suspension of PSA was dispersed on NA plates. Endophytic fungi were grown in $250 \mathrm{ml}$ Erlenmeyer flasks containing $150 \mathrm{ml}$ malt PDA liquid medium. The culture was grown with continuous shaking on a rotary shaker $(180 \mathrm{rpm})$ at $26^{\circ} \mathrm{C}$ for 3 days. After incubation, endophytic fungi were harvested by a centrifugation at $5000 \mathrm{rpm}$ for $10 \mathrm{~min}$ and $20 \mu \mathrm{l}$ of endophytic fungi extracts were pipetted into a sterile oxford-cup ( $6 \mathrm{~mm} \times 10 \mathrm{~min})$. These were placed on the surface of the plate and incubated at $30^{\circ} \mathrm{C}$ for $48 \mathrm{~h}$. Sterile water was used as a control. Antibacterial activity was measured by the diameter of the inhibition zone. For the stains that showed good bacteriostasis, 7 generation was subcultured and the subculture was tested again to make sure the stability.

\section{Results}

Three strains from three sites were obtained.

For colony Dujiangyan, there was no obvious symptom on cane No.1 during the first 8 days. It produced the reddish exudates in Day 9 with water soaked lesions appeared around the wound. For colony Shifang it was until the 11 days that the cane appeared obvious symptom: reddish exudates produced on twigs. For colony Ya/an, it took 8 days to appear the symptom on cane No.3. Bacterium with morphological, biochemical and molecular characteristics identical to the original isolate were re-isolated from tissue showing symptoms.

According to the techniques reported by Lelliott and Stead (1988), these strains were positive for levan production, tobacco-hypersensitivity reaction and metabolism of glucose. Negative for presence of oxidase, potato soft rot, arginine dihydrolase, Gram staining and the presence of fluorescent pigment on King"s medium B.

The relationship between growth and temperature was analyzed. It was demonstrated that the most suitable temperature for bacterium growth is around $28^{\circ} \mathrm{C}$ (Figure 2). It grows slowly under $0^{\circ} \mathrm{C}$ to $4^{\circ} \mathrm{C}$. 


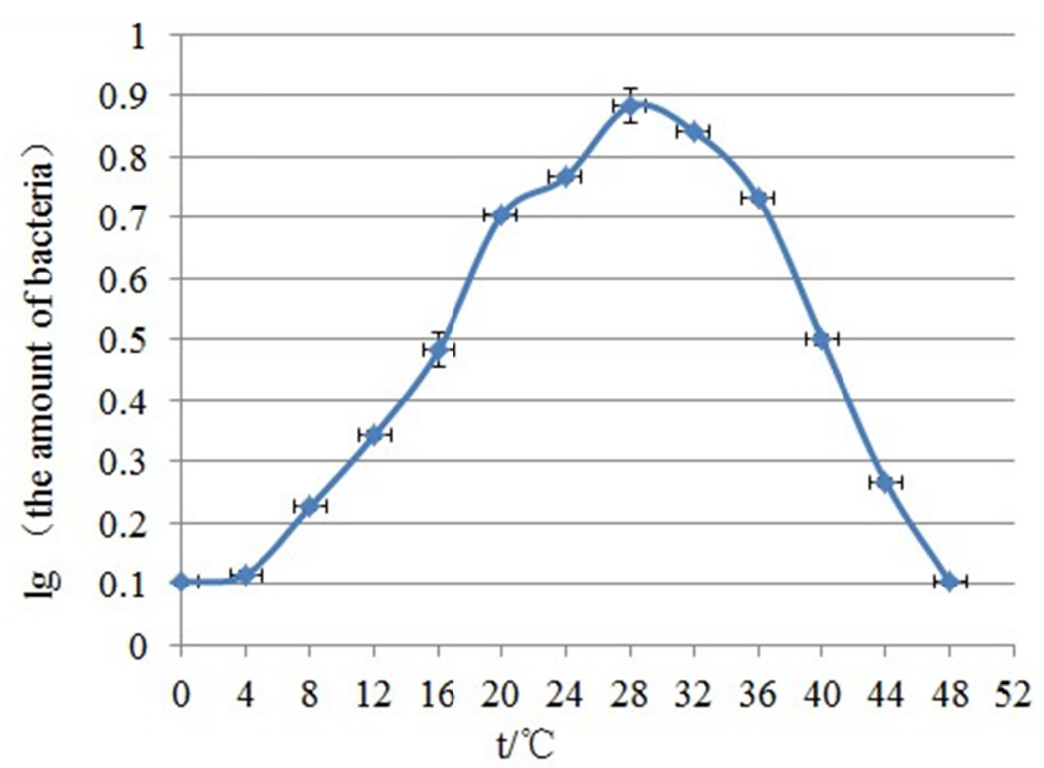

Figure 2. The relationship between growth and temperature the most suitable temperature for bacterium growth is around $28^{\circ} \mathrm{C}$ (Figure 2). It grows slowly under $0^{\circ} \mathrm{C}$ to $4^{\circ} \mathrm{C}$

In addition, the growth of bacterium was affected by culture time with a slight upward trend in the first 8 hours and increasing rapidly in the following 20 hours implying the exponential growth of bacterium is in the range from $0.18(\mathrm{lg})$ to $0.9(\mathrm{lg})$. In the period between 30 and 36 hours, there was a slight growth after which the growth stabilized at $1(\mathrm{lg})$ as Figure 3 shown.

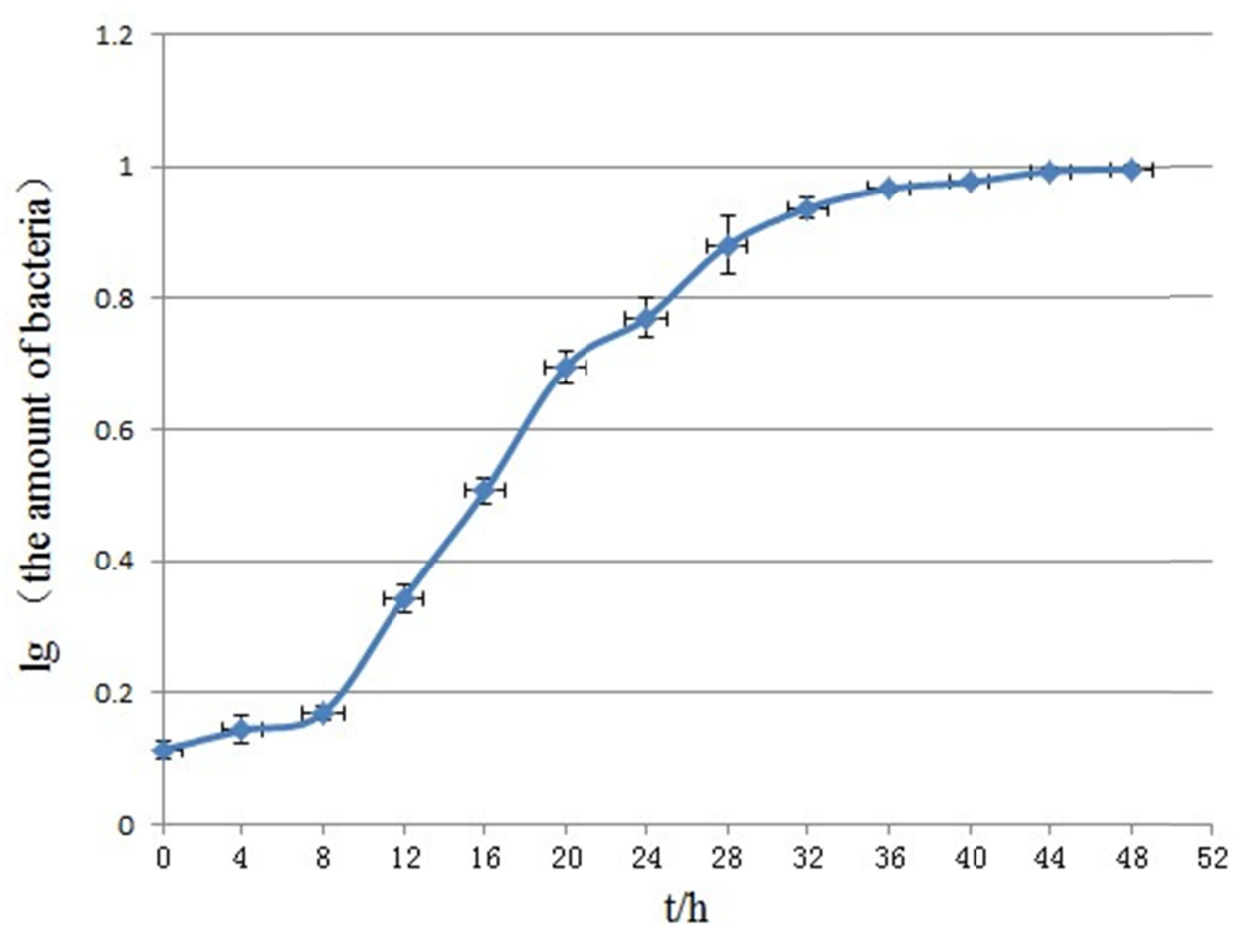

Figure 3. The relationship between bacteria growth and time: the growth of bacterium was affected by culture time with a slight upward trend in the first 8 hours and increasing rapidly in the following 20 hours implying the exponential growth of bacterium is in the range from $0.18(\mathrm{lg})$ to $0.9(\mathrm{lg})$. In the period between 30 and 36 hours, there was a slight growth after which the growth stabilized at $1(1 \mathrm{~g})$

As the Figure 4 shown, the bacterium is oval-shaped and has a smooth surface. 


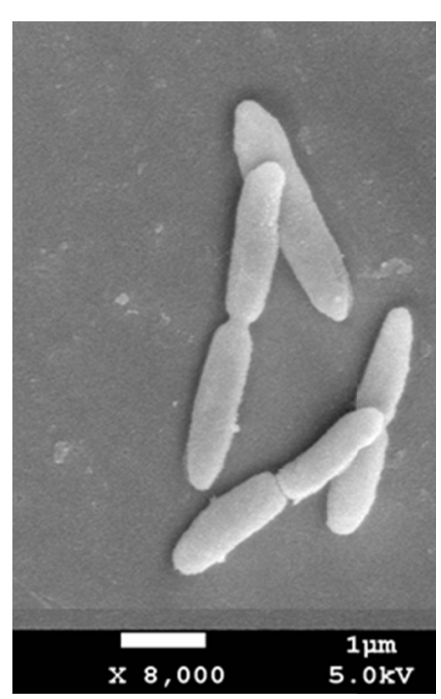

Figure 4. Shape observation of the bacteria using a scanning electronic microscope: the bacterium is oval-shaped and has a smooth surface

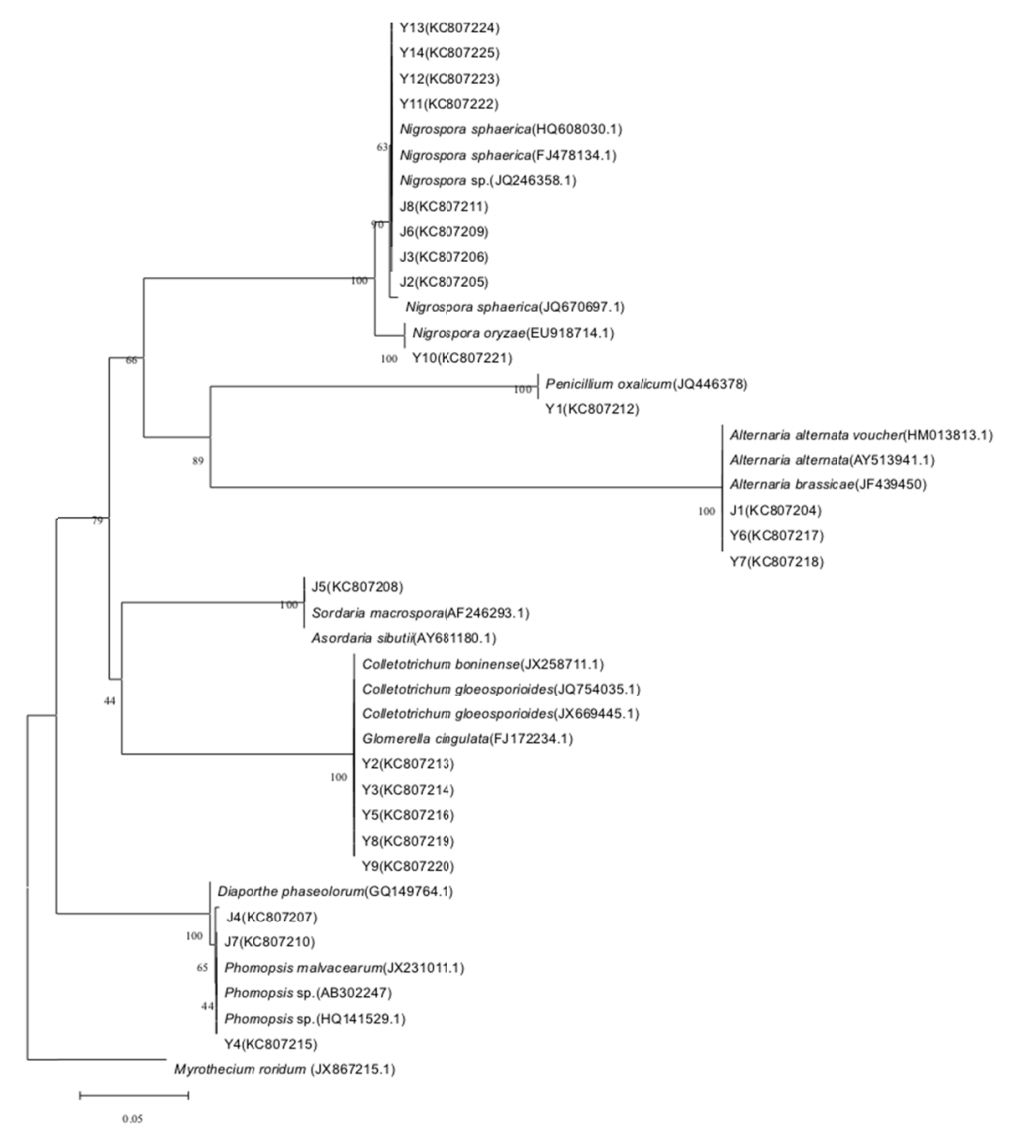

Figure 5. The phylogenetic tree of the endophytic fungi. The ITS sequences of the 22 endophytic fungi had been submitted to the GenBank in NCBI and 22 accession numbers were obtained. The 22 sequences were used as the target sequences to search the homologous sequences by the BLAST method in GenBank. High homologous sequences were selected and Myrothecium roridum was used as the outgroup to construct the phylogenetic tree by softwar MEGA 5.0 


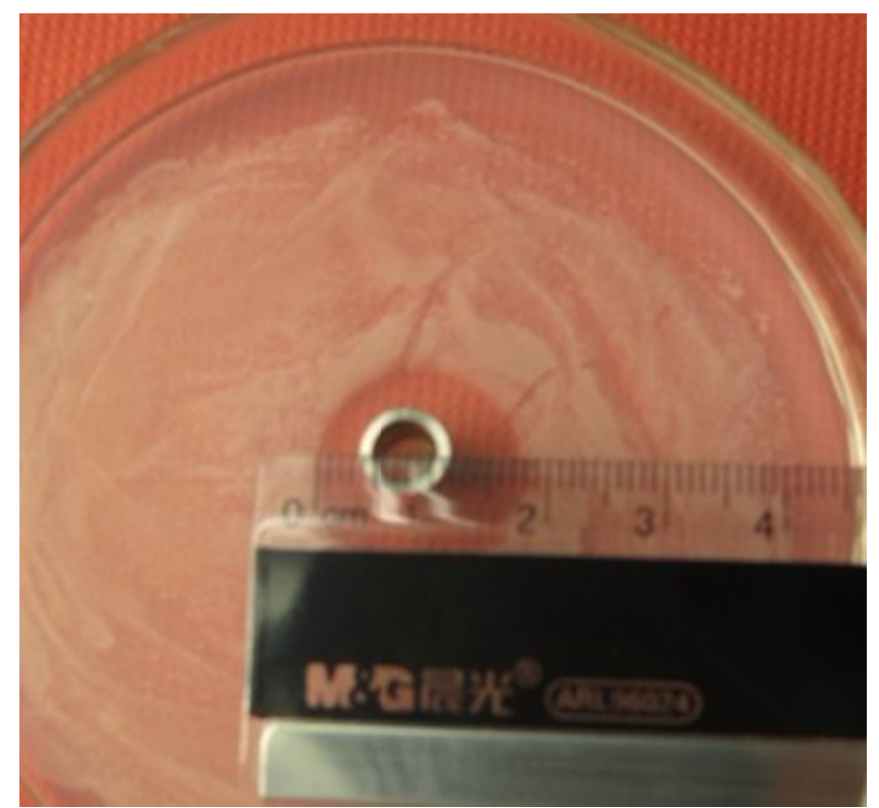

Figure 6. The inhibition zone of $\mathrm{J} 2$ : The inhibition zone of $\mathrm{J} 2$ is $14 \mathrm{~mm}$

The partial sequences of the three strains from three sites were determined and were aligned with the high similarity Pseudomonas syringae pv. actinidiae references in the GenBank database. The results confirmed that the strains from three sites were Pseudomonas syringae pv. actinidiae and do not have differences among them.

There are 8 endophytic fungi isolated from the branches of kiwifruit and 14 endophytic fungi isolated from kiwifruit leaves. The 22 endophytic fungi were used as the target sequences to search the homologous sequences by the BLAST method in GenBank. High homologous sequences were selected and Myrothecium roridum was used as outgroup to construct the phylogenetic tree by software MEGA 5.0 (Figure 5). The endophytic fungi on the leaves are more plentiful than on the branches.

As for both branches and leaves, the dominant fungus was Nigrospora.sp. One of the endophytic fungi Nigrospora sp. (No.J2 Figure 6) have the bacteriostatic effect with the inhibition zone of $14 \mathrm{~mm}$, even after seven subcultures the strain still shows good bacteriostasis.

\section{Discussion}

We first reported the endophytic fungi from kiwifruit and detected their antibacterial activity. this particular kiwifruit plant showed good resistance to kiwifruit bacterial canker in the field, the endophytic fungi in kiwifruit is rich in species, therefore it is feasible of screening for endophytic fungi resistance to kiwifruit bacterial canker. This study has been screened of the endophytic fungi: Nigrospora sp. which showed great bacteriostasis and genetic stability. In recent years, there are many papers on the antagonistic effection of Nigrospora sp. For instance, Jun-Wei He (He et al., 2012 ) isolated a compound with antiviral activity from an endolichenic fungal strain Nigrospora sp.; Wen-Jen Yang (Yang et al., 2012) isolated a red antibacterial agent from Nigrospora sp. No.407. These shows that Nigrospora sp. has the potential of being the biocontrol agent .Therefore, the further research on the generation of secondary metabolites of Nigrospora sp. (No.J2) will create a very broad prospect for the development and utilization of the kiwifruit endophytic fungi.

\section{Acknowledgements}

This work was financed by the grant from the Sichuan Provincial scientific research funds.

\section{References}

Downing, K. J., \& Thomson, J. A. (2000). Introduction of the Serratia marcescens chiA gene into an endophytic Pseudomonas fluorescens for the biocontrol of phytopathogenic fungi. Canadian journal of microbiology, 46(4), 363-369.

He, J. W., Chen, G. D., Gao, H., Yang, F., Li, X. X., Peng, T., Guo, L. D., Yao, X. S. (2012). Heptaketides with antiviral activity from three endolichenic fungal strains Nigrospora sp., Alternaria sp. and Phialophora sp. Fitoterapia, 83, 1087-1091. 
Lelliott, R. A, Stead, D. E. (1988). Methods for the Diagnasis of Bacterial Diseases of Plants. Oxford, UK: Blackwell Scientific.

Li, Y., Sung, Y. C., Liu, J. Y., Ma, Y. M., Tan, R. X. (2005). Anti-Helicobacter pyori substances from endophytic fungal cultures. World J. Microbiol Biotechnol, 21, 553-558. http://dx.doi.org/10.1007/s11274-004-3273-2

Recs-George, J., Vanneste, J. L., Cornish, D. A., Pushparajah, I. P. S., Yu, J., Templeton, M. D., \& Eerett, K. R. (2010). Detection of Pseudomonas syringae pv. actinidiae using polymerase chain reaction(PCR) primers based on the 16S-23S rDNA intertranscribed spacer region and comparison with PCR primers based on other gene regions. Plant Pathology, 59, 453-464.

Ryu, C. M., Kim, J. W., Cho, O. H., Park, S. Y., Park, S. H., \& Park, C. S. (2005). Nature of a root associated Paenibacillus poymyxa from field-grown winter barley in Korea. J. Microbiol Biolechnol, 15, 984-991.

Serizawa, S., Ichikawa, T., Takikawa, Y., Tsuyumu, S., \& Goto, M. (1989). Occurrence of bacterial canker of kiwifruit in Japan: description of symptoms, isolation of the pathogen and screening of bactericides. Annals of the Phytopathological Society of Japan, 55(4), 427-436.

Shimizu, M., Nakagawa, Y., Sato, Y., Furumai, T., Igarashi, Y., Onaka, H., ... Kunch, H. (2000). Studies on endophytic actinomycetes(I) Streptomyces sp. Isolated from Rhodooendron and its antifungal activity. J. Gen Plant Pathol, 66, 360-366. http://dx.doi.org/10.1007/PL00012978

Takikawa, Y., Serizawa, S., Ichikawa, T., Tsuyumu, S., \& Goto, M. (1989). Pseudomonas syringae pv. Actinidiae pv. nov.: the causa bacterium of canker of kiwifruit in Japan. Annals of Phytopathological, Society of Japan, 55, 437-44. http://dx.doi.org/10.3186/jjphytopath.55.437

Yang, W. J., Yang, C. S., Huang, C. J., Chen, K. S., \& Lin, S. F. (2012). Bostrycin, a novel coupling agent for protein immobilization and prevention of biomaterial-centered infection produced by Nigrospora sp. No. 407. Enzyme and Microbial Technology, 50(6), 287-292.

Wu, F., Huang, D., Huang, X. L., Zhou, X., \& Cheng, W. J. (2009). Comparing Study on Several Methods for DNA Extraction from Endophytic fungi. Chinese Agriculture Science Bulletin, 25(08), 62-64.

\section{Copyrights}

Copyright for this article is retained by the author(s), with first publication rights granted to the journal.

This is an open-access article distributed under the terms and conditions of the Creative Commons Attribution license (http://creativecommons.org/licenses/by/3.0/). 